\title{
HIDDEN DRIVERS OF SUCCESS AMONG WOMEN ENTREPRENEURS
}

\author{
*Usha Rani M.R **Dr. Cynthia Menezes
}

\begin{abstract}
:
Modern age is an age of technological advancement, rapid industrialization, urbanization and hard competition that has made an individual's life more confused and insecure. Entrepreneurship ...the very term signifies energy, innovation, passion and creativity ascribed to the men and women who build new business ventures or reviving an existing business by discovering, generating, and stimulating opportunity. The entrepreneurs act as catalyst to the new venture process, self-employment and entrepreneurship are increasingly important for women as a way to ensure income from work in the context of declining job security. Attempting to find the secret of success of certain entrepreneurs, the present paper focus on the positive emotions which may enhance entrepreneurial creativity \& opportunity recognition of women entrepreneurs. Six dimensions of emotional intelligence taken for the study and analyze has been made on 28 women entrepreneurs.
\end{abstract}

Key words : Emotional Intelligence, Enterprise, Women Entrepreneurs, Gender Empowerment

"The emotional brain responds to an event more quickly than the thinking brain?"

\section{-Daniel Goleman}

\section{Introduction}

Entrepreneurship...the very term signifies energy, innovation, passion and creativity ascribed to the men and women who build new business ventures or reviving an existing business by discovering, generating, and stimulating opportunity. The entrepreneurs act as catalyst to the new venture process.

Cole(1969) described entrepreneurship "as an activity to set up, maintain and finally earn profits from the business". Drucker (1985) described entrepreneur "as a person who maximizes opportunities and profits" emphasis that innovation as a specific function of entrepreneurship at an individual levelwhile Rosenfeld and Servo (1991) look upon the issue of innovation at an organizational level. To prepare today's entrepreneurs to be the creative, engage as community leaders of tomorrow, participating entrepreneurs must demonstrate high levels of self-confidence, trustworthiness, achievement orientation, service orientation, change catalyst, teamwork and collaboration. Trustworthiness, the ability to maintain standards of honesty and integrity requires emotional stability to carry forward the business. In this competent world an individual's personality can function effectively if he/she is free from tensions, worries and emotional disturbances. Managing

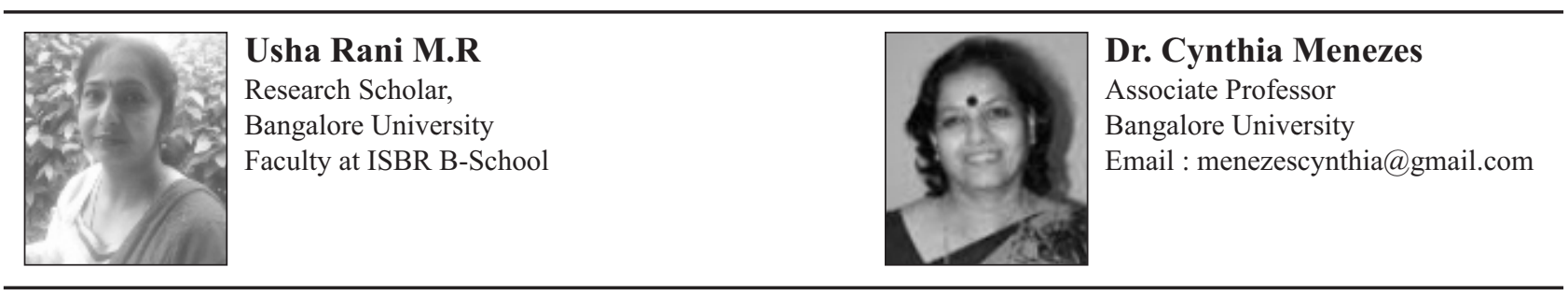


emotions helps to develop psychological resilience in people which is of utmost importance in today's world. Hence it is obvious that to enhance performance of the organization and to build up a strong leadership base characterized by leaders/entrepreneurs need to have high Emotional Intelligence(EI) coupled with highly motivated and engaged employees. Entrepreneurs must be attentive to their emotional reactions when making decisions, and the effect of their emotions on the quality of these decisions (Kida et al., 2001; Lurie, 2004).

Women in India engage in entrepreneurial activities due to pull and push factors. In pull factors, there exist an urge among women to start something new (creativity) and in push factors; women are forced to take up entrepreneurship due to monetary and economic difficulties. Self-employment and entrepreneurship are increasingly important for women as away to ensure income from work in the context of declining job security and flexibility of work contracts across India. Women Entrepreneurs may be defined as the women or a group of women who initiate, organize and operate a business enterprise. Government of India has defined women entrepreneurs as an enterprise owned and controlled by a women having a minimum financial interest of $51 \%$ of the capital and giving at least $51 \%$ of employment generated in the enterprise to women. Women entrepreneurs have been increasing in the last three decades where women from various walks of life have started new ventures that have contributed to economic development of the country. Women entrepreneurs are exploring the prospects of starting new enterprise; undertake risks, introduction of new innovations, coordination administration and control of business and providing effective leadership in all aspects of business. Bertaux and Crable (2007) conducted research on Indian female entrepreneurs in a rural region, despite the day-to-day difficulties and restrictions, the research showed encouraging data about economic development which in some regions of the country, arise from the entrepreneurial activities of women. The study also shows that women conciliate in an exemplary manner, with their domestic activity, besides contributing to the family budget.

\section{Role of women in employment:}

There has been major changes in the role of women, from being a typical homemaker, now heading some of the leading corporate giants in the world, to name - IndraNooyi, Kiran Mazumdar Shaw, Chanda Kochhar but few in number." Glass Ceiling' prevents women from reaching the top position in most position in most of the private sector companies. There is also large gap that exists between rural and urban workforce. The Eleventh Five Year Plan proposed to undertake special plan (2007-2012) measures for gender empowerment and equity. Women entrepreneurs create new businesses around their family environment and circumstances. Women entrepreneurs also actively participate in the gender, home-based and lifestyle entrepreneurship domains. This form of new venture business creation however has its own set of unique challenges, including fear of failure, less optimistic and confidence in business than men, and most importantly, securing start-up finance. Women's entrepreneurship can provide the fuel for economic growth and opportunity for communities around the world.

\section{Review of Literature}

Research indicates that positive emotions may enhance entrepreneurial creativity, including opportunity recognition (Baron, 2008). Emotional Intelligence is defined as the ability to monitor one's own feelings and emotions as 
well as the feelings and emotions of others. For entrepreneurs, the ability to understand and accurately express nonverbal emotions as well as interpret the emotional expressions of others is extremely important. For example, inrelation to entrepreneurs, the regulation of emotions assists in maintaining calm in stressful situations. Entrepreneurs must respect and understand others' emotions, thereby entrepreneurs can help inspire customers, suppliers \& employees to work hard through the art of emotional intelligence skills. Interpersonal skills, commitment and social perception are sets of entrepreneurial skills that contribute to their businesses. In the study of 299 small business owners reported in this issue, Ozcelik et al. (2007) found that business owners' attempts to facilitate a positive emotional climate in their workplaces through practices such as considering employees' emotional and personal growth and encouraging employees to share positive emotions were predictive of several organizational outcomes such as increased revenue, strategic growth (including an increase in new products/services, customers, and markets), and outcome growth (including an increase in number of customers and sales). Emotional Intelligence involves being able to handle emotions smartly. Baum (1994) developed a list of nine entrepreneurial competencies, based on works by Chandler and Jansen (1992) and Herron and Robinson (1993): knowledge, cognitive skill, self management, administration, human resources, skill in taking decisions, leadership, recognition and development of opportunities; included too, are human relations and entrepreneurial practices. The research conducted by Lerner and Almor (2002) with the use of a Likert scale applied to a sample of 220 Israeli business women demonstrated that, the managerial competencies (in finance, human resources, operations and strategy) are distinct from what he regards as entrepreneurial competencies (innovation andmarketing). Women brought their personal passions, convictions, energies, and strengths to their innovative efforts and exercise entrepreneurial skills. Zarifian (1999) relates competency to the capacity of a person to assume initiatives, to go beyond the prescribed activities, to understand and master new work situations, to be responsible and be recognized. Drucker (1985), in his work Innovation and Entrepreneurship, argues that these two concepts, taken together, are the driving forces of revitalization in any entrepreneurial society. Anthropologists have noted that appropriate emotional displays and recognition of the emotional displays of others are essential for successful functioning and leadership in primate societies (Boehm,1999). Professor Judy Rosener found that men and women have distinctive leadership styles with respect to enterprising skills, innovativeness \& creativity, with men more likely to view leadership as a sequence of business transactions with others, whereas women are more transformational, using interpersonal skills to motivate followers rather than applying positional power or authority. Alice Eagly and colleagues, observed that women lead in a more democratic and participative style than men, and argue that evaluation of women leaders' effectiveness depends on several interacting variables including work context and culture.

\section{Research Gap:}

Competition has become an inherent factor for sustainability in the business; there is a great need to evaluate emotional stability on different parameters and it can be found. An attempt has been made in the study to analyze the factors that are essential in influencing decisions on the business. 


\section{Aim of the Study:}

The objective of the study is to examine the emotional intelligence traits on women entrepreneurs and its impact on their business. Women entrepreneurship has been documented during the last decade as an important unexploited source of economic growth. Emotional Intelligence is considered to be an innate characteristic that enables and promotes well-being,EI traits can be reflected on performance. This topicis currently very important since it is part of ongoing national campaign such as Skill India, Make in India to boost entrepreneurship indeveloping countries like India.

\section{Objectives of the study:}

- To identify the different dimensions of emotional intelligence on women entrepreneurship.

- To analyze the implication of the results on the business.

\section{Methodology:}

The study is descriptive analysis and convenience sampling technique adopted. Primary data has been collected through structured questionnaire method through online was developed with five point rating scale with ranging from strongly agree to strongly disagree on emotional intelligence variables such as Self awareness, Self motivation, Emotional stability, Managing relations, Self development from 28 respondents. The secondary data is gathered through literature review, books.

\section{Statistical Tools:}

Data Analysis was done using Statistical Package for social Science (SPSS) version 20.0 for the data gathered through structured questionnaire: Mean, Standard Deviation, Correlation analysis was used as statistical tools.

\section{Dimension 1: Self Awareness}

Correlation-Self Awareness

\begin{tabular}{|c|c|c|c|c|c|}
\hline & & $\begin{array}{l}\text { continue to } \\
\text { work with } \\
\text { severe } \\
\text { criticisms }\end{array}$ & $\begin{array}{l}\text { priorities } \\
\text { clear }\end{array}$ & $\begin{array}{l}\text { believe } \\
\text { myself }\end{array}$ & $\begin{array}{l}\text { built rapport } \\
\text { with work } \\
\text { associations }\end{array}$ \\
\hline \multirow{5}{*}{$\begin{array}{l}\text { continue to work with } \\
\text { severe criticisms }\end{array}$} & Pearson Correlation & 1 & $.713^{* * 2}$ & $.607^{* * 4}$ & .206 \\
\hline & Sig. (2-tailed) & & .000 & .001 & .294 \\
\hline & $\begin{array}{l}\text { Sum of Squares and Cross- } \\
\text { products }\end{array}$ & 14.857 & 11.000 & 8.429 & 1.714 \\
\hline & Covariance & .550 & .407 & .312 & .063 \\
\hline & $\mathrm{N}$ & 28 & 28 & 28 & 28 \\
\hline \multirow[t]{4}{*}{ priorities clear } & Pearson Correlation & $.713^{* *}$ & 1 & $.764^{* *}$ & .347 \\
\hline & $\begin{array}{l}\text { Sig. (2-tailed) } \\
\text { Sum of Squares and Cross- } \\
\text { products }\end{array}$ & $\begin{array}{r}.000 \\
11.000\end{array}$ & 16.000 & $\begin{array}{r}.000 \\
11.000\end{array}$ & $\begin{array}{r}.071 \\
3.000\end{array}$ \\
\hline & Covariance & .407 & .593 & .407 & .111 \\
\hline & $\mathrm{N}$ & 28 & 28 & 28 & 28 \\
\hline \multirow{5}{*}{ believe myself } & 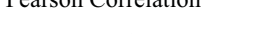 & .001 & .104 & 1 & .142 \\
\hline & Sig. (2-tailed) & .001 & .000 & & .471 \\
\hline & $\begin{array}{l}\text { Sum of Squares and Cross- } \\
\text { products }\end{array}$ & 8.429 & 11.000 & 12.964 & 1.107 \\
\hline & Covariance & .312 & .407 & .480 & .041 \\
\hline & $\mathrm{N}$ & 28 & 28 & 28 & 28 \\
\hline \multirow{5}{*}{$\begin{array}{l}\text { built rapport with work } \\
\text { associations }\end{array}$} & Pearson Correlation & .206 & .347 & .142 & 1 \\
\hline & Sig. (2-tailed) & .294 & .071 & .471 & \\
\hline & $\begin{array}{l}\text { Sum of Squares and Cross- } \\
\text { products }\end{array}$ & 1.714 & 3.000 & 1.107 & 4.679 \\
\hline & Covariance & .063 & .111 & .041 & .173 \\
\hline & $\mathrm{N}$ & 28 & 28 & 28 & 28 \\
\hline
\end{tabular}

**. Correlation is significant at the 0.01 level (2-tailed). 
The results project that there is positive correlation between emotional intelligence (Self Awareness) on women entrepreneurs in taking decisionsrelating to the business activities.

\section{Dimension 2:Self Motivation}

Correlation- Self Motivation

\begin{tabular}{|c|c|c|c|c|c|c|c|}
\hline & & inspire others & $\begin{array}{c}\text { take } \\
\text { intelligent } \\
\text { decisions }\end{array}$ & $\begin{array}{l}\text { assess } \\
\text { situation }\end{array}$ & $\begin{array}{c}\text { concentrate } \\
\text { with } \\
\text { disturbance }\end{array}$ & $\begin{array}{l}\text { feelings } \\
\text { managed }\end{array}$ & $\begin{array}{l}\text { positive } \\
\text { attitude }\end{array}$ \\
\hline \multirow{6}{*}{$\begin{array}{l}\text { inspire } \\
\text { others }\end{array}$} & Pearson & 1 & .520 & .600 & .291 & .534 & $.503^{\mathrm{m}}$ \\
\hline & Sig. (2-tailed) & & .005 & .001 & .133 & .004 & .009 \\
\hline & Sum of & 7.714 & 5.857 & 5.000 & 2.571 & 4.667 & 4.654 \\
\hline & $\begin{array}{l}\text { Squares and } \\
\text { Cross-products }\end{array}$ & & & & & & \\
\hline & Covariance & .286 & .217 & .185 & .095 & .179 & .186 \\
\hline & $\mathrm{N}$ & 28 & 28 & 28 & 28 & 27 & 26 \\
\hline \multirow{6}{*}{$\begin{array}{l}\text { take } \\
\text { intelligent } \\
\text { decisions }\end{array}$} & Pearson & $.520^{* *}$ & 1 & $.576^{* *}$ & $.449^{*}$ & $.474^{*}$ & $.631^{* *}$ \\
\hline & $\begin{array}{l}\text { Correlation } \\
\text { Sig. (2-tailed) }\end{array}$ & .005 & & .001 & .017 & .012 & .001 \\
\hline & Sum of & 5.857 & 16.429 & 7.000 & 5.786 & 6.000 & 8.731 \\
\hline & $\begin{array}{l}\text { Squares and } \\
\text { Cross-products }\end{array}$ & & & & & & \\
\hline & Covariance & .217 & .608 & .259 & .214 & .231 & .349 \\
\hline & $\mathrm{N}$ & 28 & 28 & 28 & 28 & 27 & 26 \\
\hline \multirow{5}{*}{$\begin{array}{l}\text { assess } \\
\text { situation }\end{array}$} & $\begin{array}{l}\text { Pearson } \\
\text { Correlation }\end{array}$ & $.600^{\prime \prime \prime}$ & .576 & 1 & .472 & .735 & .715 \\
\hline & Sig. (2-tailed) & .001 & .001 & & .011 & .000 & .000 \\
\hline & $\begin{array}{l}\text { Sum of } \\
\text { Squares and } \\
\text { Cross-products }\end{array}$ & 5.000 & 7.000 & 9.000 & 4.500 & 6.000 & 6.308 \\
\hline & Covariance & .185 & .259 & .333 & .167 & .231 & .252 \\
\hline & & 28 & 28 & 28 & 28 & 27 & 26 \\
\hline \multirow{4}{*}{$\begin{array}{l}\text { concentrate } \\
\text { with } \\
\text { disturbance }\end{array}$} & $\begin{array}{l}\text { Pearson } \\
\text { Correlation }\end{array}$ & .291 & $.449^{*}$ & $.472^{*}$ & 1 & $.400^{*}$ & $.434^{*}$ \\
\hline & Sig. (2-tailed) & .133 & .017 & .011 & & .039 & .027 \\
\hline & $\begin{array}{l}\text { Sum of } \\
\text { Squares and }\end{array}$ & 2.571 & 5.786 & 4.500 & 10.107 & 4.000 & 4.731 \\
\hline & Covariance & .095 & .214 & .167 & .374 & .154 & .189 \\
\hline \multirow{5}{*}{$\begin{array}{l}\text { feelings } \\
\text { managed }\end{array}$} & $\begin{array}{l}\mathrm{N} \\
\text { Pearson }\end{array}$ & $\begin{array}{r}28 \\
534^{* *}\end{array}$ & $\begin{array}{r}28 \\
474^{*}\end{array}$ & $\begin{array}{r}28 \\
735^{* *}\end{array}$ & 28 & 27 & 26 \\
\hline & Correlation & & & & & & \\
\hline & Sig. (2-tailed) & .004 & .012 & .000 & .039 & & .001 \\
\hline & $\begin{array}{l}\text { Sum of } \\
\text { Squares and } \\
\text { Cross-products }\end{array}$ & 4.667 & 6.000 & 6.000 & 4.000 & 10.000 & 5.923 \\
\hline & Covariance & $\begin{array}{r}.179 \\
27\end{array}$ & $\begin{array}{r}.231 \\
27\end{array}$ & $\begin{array}{r}.231 \\
27\end{array}$ & $\begin{array}{r}.154 \\
27\end{array}$ & $\begin{array}{r}.385 \\
27\end{array}$ & $\begin{array}{r}.237 \\
26\end{array}$ \\
\hline \multirow{5}{*}{$\begin{array}{l}\text { positive } \\
\text { attitude }\end{array}$} & Pearson & $.503^{*+*}$ & $.631^{k+}$ & $.715^{* *}$ & $.434^{*}$ & $.598^{*+*}$ & $\begin{array}{r}20 \\
1\end{array}$ \\
\hline & $\begin{array}{l}\text { Correlation } \\
\text { Sig. (2-tailed) }\end{array}$ & .009 & .001 & .000 & .027 & .001 & \\
\hline & $\begin{array}{l}\text { Sum of } \\
\text { Squares and } \\
\text { Cross-products }\end{array}$ & 4.654 & 8.731 & 6.308 & 4.731 & 5.923 & 12.038 \\
\hline & Covariance & .186 & .349 & .252 & .189 & .237 & .482 \\
\hline & $\mathrm{N}$ & 26 & 26 & 26 & 26 & 26 & 26 \\
\hline
\end{tabular}

**. Correlation is significant at the 0.01 level (2-tailed).

*. Correlation is significant at the 0.05 level (2-tailed).

The result reflects that there is positive correlation between emotional intelligence (Self Motivation) on women entrepreneurs in taking decisions and manage business activities. 


\section{Dimension 3: Emotional Stability}

\section{Correlations-Emotional stability}

\begin{tabular}{|c|c|c|c|c|c|}
\hline & & $\begin{array}{l}\text { emotions not } \\
\text { mixed with } \\
\text { issues }\end{array}$ & $\begin{array}{l}\text { stable with } \\
\text { situations }\end{array}$ & $\begin{array}{l}\text { open novel } \\
\text { ideas }\end{array}$ & $\begin{array}{l}\text { persistent in } \\
\text { pursuing goals }\end{array}$ \\
\hline \multirow{3}{*}{$\begin{array}{l}\text { emotions not mixed } \\
\text { with issues }\end{array}$} & Pearson Correlation & 1 & .521 & .519 & .455 \\
\hline & $\begin{array}{l}\text { Sig. (2-tailed) } \\
\text { Sum of Squares and } \\
\text { Cross-products }\end{array}$ & 15.000 & $\begin{array}{r}.005 \\
6.000\end{array}$ & $\begin{array}{r}.005 \\
8.000\end{array}$ & $\begin{array}{r}.015 \\
7.500\end{array}$ \\
\hline & $\begin{array}{l}\text { Covariance } \\
\mathrm{N} \\
\text { Pearson Correlation }\end{array}$ & $\begin{array}{r}.556 \\
28 \\
.521^{* *}\end{array}$ & $\begin{array}{r}.222 \\
28 \\
1\end{array}$ & $\begin{array}{r}.296 \\
28 \\
.518^{* *}\end{array}$ & $\begin{array}{r}.278 \\
28 \\
.620^{*+}\end{array}$ \\
\hline \multirow{2}{*}{$\begin{array}{l}\text { stable with } \\
\text { situations }\end{array}$} & $\begin{array}{l}\text { Sig. (2-tailed) } \\
\text { Sum of Squares and } \\
\text { Cross-products }\end{array}$ & $\begin{array}{r}.005 \\
6.000\end{array}$ & 8.857 & $\begin{array}{r}.005 \\
6.143\end{array}$ & $\begin{array}{r}.000 \\
7.857\end{array}$ \\
\hline & $\begin{array}{l}\text { Covariance } \\
\mathrm{N} \\
\text { Pearson Correlation }\end{array}$ & $\begin{array}{r}.222 \\
28 \\
.519^{* *}\end{array}$ & $\begin{array}{r}.328 \\
28 \\
.518^{* *}\end{array}$ & $\begin{array}{r}.228 \\
28 \\
1\end{array}$ & $\begin{array}{r}.291 \\
28 \\
.746^{*+}\end{array}$ \\
\hline \multirow{2}{*}{ open novel ideas } & $\begin{array}{l}\text { Sig. (2-tailed) } \\
\text { Sum of Squares and } \\
\text { Cross-products }\end{array}$ & $\begin{array}{r}.005 \\
8.000\end{array}$ & $\begin{array}{r}.005 \\
6.143\end{array}$ & 15.857 & $\begin{array}{r}.000 \\
12.643\end{array}$ \\
\hline & $\begin{array}{l}\text { Covariance } \\
\mathrm{N} \\
\text { Pearson Correlation }\end{array}$ & $\begin{array}{r}.296 \\
28 \\
.455^{*}\end{array}$ & $\begin{array}{r}.228 \\
28 \\
.620^{*+*}\end{array}$ & $\begin{array}{r}.587 \\
28 \\
.746\end{array}$ & $\begin{array}{r}.468 \\
28 \\
1\end{array}$ \\
\hline \multirow{3}{*}{$\begin{array}{l}\text { persistent in } \\
\text { pursuing goals }\end{array}$} & Sig. (2-tailed) & .015 & .000 & .000 & \\
\hline & $\begin{array}{l}\text { Sum of Squares and } \\
\text { Cross-products }\end{array}$ & 7.500 & 7.857 & 12.643 & 18.107 \\
\hline & $\begin{array}{l}\text { Covariance } \\
\mathrm{N}\end{array}$ & $\begin{array}{r}.278 \\
28\end{array}$ & $\begin{array}{r}.291 \\
28\end{array}$ & $\begin{array}{r}.468 \\
28\end{array}$ & $\begin{array}{r}.671 \\
28\end{array}$ \\
\hline
\end{tabular}

**. Correlation is significant at the 0.01 level (2-tailed).

*. Correlation is significant at the 0.05 level (2-tailed).

The results depicts that there is positive correlation between Emotional Intelligence (Emotional Stability)on women entrepreneurs in taking decisions and managebusiness activities.

\section{Dimension 4: Managing Relations}

\section{Correlation- Managing Relations}

\begin{tabular}{|c|c|c|c|c|c|}
\hline & & $\begin{array}{c}\text { perceived as } \\
\text { friendly } \\
\text { outgoing } \\
\end{array}$ & $\begin{array}{c}\text { others } \\
\text { encouragement }\end{array}$ & $\begin{array}{c}\text { look for } \\
\text { brighter side } \\
\end{array}$ & $\begin{array}{c}\text { maintain rapport } \\
\text { with others }\end{array}$ \\
\hline \multirow{4}{*}{$\begin{array}{l}\text { perceived as friendly } \\
\text { outgoing }\end{array}$} & Pearson Correlation & 1 & .472 & .237 & .189 \\
\hline & Sig. (2-tailed) & & .011 & .224 & .345 \\
\hline & Sum of Squares and & .964 & 1.536 & .929 & .481 \\
\hline & Covariance & .036 & .057 & .034 & .019 \\
\hline \multirow{5}{*}{$\begin{array}{l}\text { others } \\
\text { encouragement }\end{array}$} & $\mathrm{N}$ & 28 & 28 & 28 & 27 \\
\hline & Pearson Correlation & .472 & 1 & .688 & .681 \\
\hline & $\begin{array}{l}\text { Sig. (2-tailed) } \\
\text { Sum of Squares and }\end{array}$ & $\begin{array}{r}.011 \\
1.536\end{array}$ & 10.964 & $\begin{array}{r}.000 \\
9.071\end{array}$ & $\begin{array}{r}.000 \\
5.778\end{array}$ \\
\hline & Covariance & .057 & .406 & .336 & .222 \\
\hline & & 28 & 28 & 28 & 27 \\
\hline \multirow[t]{4}{*}{ look for brighter side } & Pearson Correlation & .237 & $.688^{* 4}$ & 1 & .770 \\
\hline & $\begin{array}{l}\text { Sig. (2-tailed) } \\
\text { Sum of Squares and } \\
\text { Cross-products }\end{array}$ & $\begin{array}{l}.224 \\
.929\end{array}$ & $\begin{array}{r}.000 \\
9.071\end{array}$ & 15.857 & $\begin{array}{r}.000 \\
7.963\end{array}$ \\
\hline & Covariance & .034 & .336 & 587 & .306 \\
\hline & $\mathrm{N}$ & 28 & 28 & 28 & 27 \\
\hline \multirow{5}{*}{$\begin{array}{l}\text { maintain rapport with } \\
\text { others }\end{array}$} & Pearson Correlation & 189 & $.681^{\prime \prime}$ & .770 & 1 \\
\hline & Sig. (2-tailed) & .345 & .000 & .000 & \\
\hline & $\begin{array}{l}\text { Sum of Squares and } \\
\text { Cross-products }\end{array}$ & .481 & 5.778 & 7.963 & 6.741 \\
\hline & Covariance & .019 & .222 & .306 & .259 \\
\hline & $\mathrm{N}$ & 27 & 27 & 27 & 27 \\
\hline
\end{tabular}

*. Correlation is significant at the 0.05 level (2-tailed).

**. Correlation is significant at the 0.01 level (2-tailed).

The results depicts that there is positive correlation between Emotional Intelligence (Managing Relation) on women entrepreneurs in taking decisions and managebusiness activities. 
Correlation-Self Development

\begin{tabular}{|c|c|c|c|}
\hline & & $\begin{array}{c}\text { identify \& separate } \\
\text { emotions }\end{array}$ & $\begin{array}{l}\text { interested to develop } \\
\text { individually }\end{array}$ \\
\hline \multirow{4}{*}{$\begin{array}{l}\text { identify \& separate } \\
\text { emotions }\end{array}$} & Pearson Correlation & 1 & $.600^{\prime \prime \prime}$ \\
\hline & Sig. (2-tailed) & & .001 \\
\hline & $\begin{array}{l}\text { Sum of Squares and Cross- } \\
\text { products }\end{array}$ & 10.429 & 6.500 \\
\hline & Covariance & .386 & .241 \\
\hline \multirow{5}{*}{$\begin{array}{l}\text { interested to develop } \\
\text { individually }\end{array}$} & $\begin{array}{l}\mathrm{N} \\
\text { Pearson Correlation }\end{array}$ & .28 & $\begin{array}{r}28 \\
1\end{array}$ \\
\hline & Sig. (2-tailed) & .001 & \\
\hline & $\begin{array}{l}\text { Sum of Squares and Cross- } \\
\text { products }\end{array}$ & 6.500 & 11.250 \\
\hline & Covariance & .241 & .417 \\
\hline & $\mathrm{N}$ & 28 & 28 \\
\hline
\end{tabular}

The results depicts that there is positive correlation between Emotional Intelligence (Self Development) on women entrepreneurs in taking decisions and manage business activities.

\section{Conclusion:}

Managing emotions helps to develop psychological resilience in people which is of utmost importance in today's world. Rapid growth of women's self-employment and entrepreneurship corroborates that this is a significant avenue to improve women's employability. It is true, entrepreneurs must regulate emotions and remain calm in stressful situations. Entrepreneurs must respect and understand others' emotions; thereby entrepreneurs can help inspire customers, suppliers \& employees to work hard through the art of emotional intelligence skills. Participating entrepreneurs reported that they could demonstrate high levels of selfconfidence, trustworthiness, achievement orientation, service orientation, teamwork and collaboration.

\section{References:}

Amy E. Boren "Emotional Intelligence: The secret of successful entrepreneurshipfi" (2010). Inter- American Institute for Cooperation on Agriculture, vol.2, pp.55

http://digitalcommons.unl.edu/aglecfacpub/55
Diane Chandler "What Women Bring to the Exercise of Leadership" Journal of Strategic Leadership Vol.3 Iss.2 pp1-12, ISSN1941-4668

Satpal, RatheeRupa and RajainPallavi, “ Challenges faced by Women Entrepreneurs in present Technological Era", International Journal of Advanced Industrial Engineering ISSN $2320-5539$

Ray Sarbapriya, Aditya Ray Ishita "Some aspects of women entrepreneurship in India", Asian Journal of Management Research, ISSN2229-3795

Vânia Maria Jorge Nassif, Tales Andreassi, Maria Jose Tonelliand\&Maria TerezaLeme Fleury "Women entrepreneurs: Discussion about their competencies", African Journal of Business Management Vol. 6(26), pp. 76947704, 4 July, 2012, ISSN 1993-8233

Patrick Harold\& Rao Tripti(2012), "Personality Challenges of Women Entrepreneurs and Employees"- International Conference on Challenges of sustainability \& Growth in Indian Industry, 